\title{
Patterns of Resource Use for Tourism Development in Mountainous Communities in Ukraine
}

\author{
Yaroslava Korobeinykova \\ Department of Tourism, Ivano-Frankivsk National Technical University of Oil and Gas, Ukraine. \\ Email: yaroslava.korob@gmail.com | ORCID: 0000-0002-4882-8611
}

How to cite this paper: Korobeinykova, Y. (2021). Patterns of Resource use for Tourism Development in Mountainous Communities in Ukraine. Grassroots Journal of Natural Resources, 4(1): 17-28. Doi: https://doi.org/10.33002/nr2581.6853.040102

Received: 17 February 2021

Reviewed: 27 February 2021

Provisionally Accepted: 03 March 2021

Revised: 10 March 2021

Finally Accepted: 14 March 2021

Published: 25 March 2021

Copyright (C) 2021 by author(s)

This work is licensed under the Creative

Commons Attribution International

License (CC BY 4.0).

http://creativecommons.org/licenses/by/4.0/

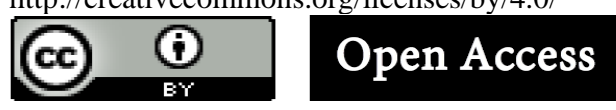

\begin{abstract}
The purpose of this article is to identify the problems associated with the tourism resource utilization in mountainous communities of Ukraine. Developing tourism at local level is a priority in the region of Ivano-Frankivsk, especially in the context of decentralization process in Ukraine. A survey was conducted involving the managers of hospitality establishments during the "active" tourist season from July to August 2019. Main parameters selected for this inquiry included the water consumption (in the form of drainage), solid waste disposal, and the quantum of electricity consumed. Data of water consumption (drainage), consumed electricity, and solid waste disposal in the surveyed hospitality establishments reflects proportional growth of the tourism manifesting accommodated tourists, capacity, and category of the hospitality establishments. On priority, identified problems of resource utilization encompass waste management, water supply, sewerage, energy supply and incom ing tourist flows. Quantitative forecasting of environmental load to be exerted by tourism development is necessary when planning resource utilization and livelihood systems of mountainous communities.
\end{abstract}

Keywords

Decentralization; Tourism; Hospitality; Resource utilization

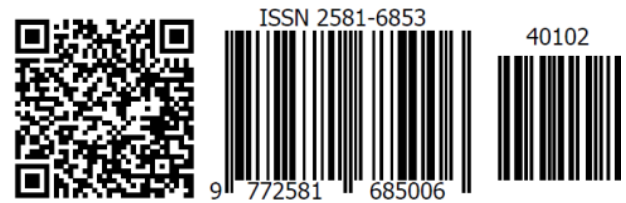


Grassroots Journal of Natural Resources, Vol.4, No.1 (March 2021), pp.17-28 | ISSN: 2581-6853 | CODEN: GJNRA9

Doi: https://doi.org/10.33002/nr2581.6853.040102

OPEN OACCESS Freely available online

\section{Introduction}

Decentralization of the local administration system in Ukraine began in 2015 and is continuing till now. It is accompanied by the formation of local institutions and the creation of roadmaps for community development. For the mountainous territorial communities or OTGs ${ }^{1}$ of Ukraine, the promising sectors of the economy are forestry and forest processing, tourism development, development of infrastructure, especially transport and roads, development of energy-saving eco-friendly industries, development of traditional mountain agriculture, and revival and development of traditional crafts and handicrafts. Powerful natural and historical-cultural potential in combination with preserved ethnic traditions and traditional crafts have formed the basis for the development of tourism in the Ivano-Frankivsk region of Ukraine. The region also has the highest potential for nature reserves in Ukraine. The tourism industry does not require significant investment and has a fast payback period for projects. Given the stable dynamics of the industry, the contribution of tourism to the region's economy was $12.86 \%$ in 2019. Gross value added in the field of tourism in 2019 was $8.27 \%$ according to the National Tourism Organization of Ukraine (National Tourist Organization of Ukraine, 2020a). Locally formed territorial communities (OTGs) define tourism as a priority area of economic development. As the experience of cooperation with local communities in the field of tourism shows, they require not only a better study of the recreational and tourist potential of their local community but also support many other activities. Among such activities are:

- formation of investment proposals for the development of certain types of tourism in the local community;

- development and planning of the projects for recreational park areas;

- development of the programs to promote local tourism products linking tourism services;

- creation of databases of resource potential and infrastructural components for tourism development;

- outlining projects encompassing improvement of tourist infrastructure in community areas;

- creation of excursion programs within the community areas; and

- consultations on the possibility of development of rural tourism in community areas.

Various studies on environmental aspects of the development of local communities are undertaken by the scientific community under the auspices of the United Nations Environment Program (UNEP). One set of such research emphasized the environmental impact of tourism in general (Holden, 2016; Davies and Cahill, 2000) and the environmental impact of tourism in the context of the hotel industry (Rabbany et al., 2013). The problem of wastes generated by tourist destinations is covered in more detail in the scientific literature. Nair and Jayakumar (2008) studied waste management in the context of rural tourism. Scientific factors influencing the quantity of the generated waste were explored by Khajuria, Yamamoto and Morioka (2010). The research conducted by Romanian specialists in the tourist destination of Bicaz-Chei is especially relevant for Ukrainian territories because of the close territorial proximity and similarity of conditions (Mihai, 2013). The researchers have elaborated tourism as a source of waste generation both in urban and rural destinations. A pertinent analysis of the impact of tourism on waste generation is performed in the article authored by Mateu-Sbert et al. (2013). An important study was carried out in EU countries on waste management in relation to tourism development (Ezeah, Fazakerley and Byrne, 2015). Noticeably, regional aspects of the environmental impact of tourism are covered in the publications of Peterson (2013), Bashir and Goswami (2016) and Giulietti et al. (2018). These studies explain the problems at some popular destinations around the world, which are currently under active development. There are only a few Ukrainian authors who cover the environmental consequences of tourism, and their articles are rather general. Ways to ensure environmental safety as part of balanced development of the tourism industry are set out in the research published by Kutsenko (2010), Prygara (2014) and Sharko (2014).

Within the Carpathian region, the main environmental impacts of tourist destinations are changes in primary landscapes, water pollution, the problem of waste management (Korobeinykova and Murava, 2013). One of

\footnotetext{
${ }^{1}$ OTG is an association of territorial communities of a village, settlement or city, which border on each other. Related documents are available on the link: https://zakon.rada.gov.ua/laws/show/157-19\#Text 
the previous publications estimate the quantity of generated waste within the Carpathian region of Ukraine. The problem of tourism resource use is further complicated by the fact that today most of the solid waste landfills in the Ivano-Frankivsk region are filled by an average of $80-90 \%$ or completely exhausted. The least equipped landfills for solid wastes are the most popular tourist communities: Yaremche City Council and Kosiv (Murava and Korobeinykova, 2016).

International experience in the conceptualization and implementation of territorial development strategies is gained with the inconsistency of Ukrainian legislation with the regulatory framework of other countries. Often, such experiences become irrelevant in particular contexts of mountainous local communities of the Ivano-Frankivsk region. A large number of publications by domestic scientists are devoted to the reform of territorial management. The most important publications in the area are by Berdanova and Vakulenko (2012), Borodina (2016), and Tkachuk, Kashevskyi and Mavko (2016). These publications highlight the general aspects and problems of local governance reform and developed methodological tools for strategic development planning for small local communities. Under the Ukrainian legislation (Cabinet of Ministers of Ukraine, 2014a), a sufficient scientific basis for the legal and financial aspects of decentralization of power in Ukraine has been developed. The issue of effective resource utilization planning in communities is unfortunately left unattended. This issue is currently weakly addressed in the development of communities in general, the development of their livelihood systems, solving environmental problems, and so on. Most of the Ukrainian research concentrates on the distribution of powers between districts, regions, and territorial communities, organizational and legal aspects of decentralization, basic concepts, principles, models, and types of decentralization, and financial implications of reforms. However, such research covers mainly the theoretical aspects of the decentralization process in Ukraine, while the practical manifestations are still left out. Unfortunately, the decentralization processes are slow, and new problems arise faster than the old ones are solved. This is a grim reality of the implementation of a state-initiated socio-economic experiment of decentralization.

The reform of the administrative-territorial system in Ukraine is a multi-stage and cumbersome process in multiple areas of livelihood and development of the society. According to the legislation of Ukraine (Cabinet of Ministers of Ukraine, 2014a), territorial communities (OTGs) have gained the right to manage land resources within their territory and to arrange cooperation between the neighbouring communities. The practical implementation of the decentralization process began only in 2015 and is still progressing very slowly. Constituted local communities have faced several problems that make their effective development impossible. Firstly, different territorial communities vary in terms of resource potential and socio-economic status. Some of them rely mainly on government allocations. On the other hand, financial decentralization has led to the accumulation of funds in local communities, which is not always rationally utilized. Secondly, the huge burden of a community support system that has not been addressed for more than thirty years has fallen on the newly formed administrative units, i.e., OTGs. Thirdly, as the governing bodies of most of the local communities need qualified managers from a variety of technical fields, remote communities lack such staff, who should not only solve urgent problems of community affairs but also work for the future projects outlining strategic directions of community development. Additionally, the implementation of strategies faces an inconsistency highlighting legislative constraints. Most of the communities do not have an information base and appropriate methodologies that will enable the successful implementation of tourism projects.

In the situation of newly constituted local communities, the question of rational planning of social and economic development in new administrative formations becomes more relevant. Mountainous local communities occupy more than $50 \%$ of the territory of the Ivano-Frankivsk region, so their successful development as independent, self-governing bodies is the key to the regional development. The past experiences of the executed projects on tourism development of the local mountainous communities in the Ivano-Frankivsk region reveal that all mountainous communities have identified tourism as a priority area for community development. However, the functions of tourism management are carried out by specialists, mainly in the cultural sphere, in some cases, and such managers were not tourism professionals (Perederko, 2021). 
Weak implementation of environmental legislation in Ukraine, low level of environmental awareness of citizens and responsible managers, and lack of comprehensive environmental management programs lead to a negative impact of tourism on the environment of tourism destinations. The poor resource management practices that are being practiced in the local communities are lacking the fundamental understanding of the problem. Moreover, improper approaches to the development of tourist infrastructure in certain regions are disrupting the local environment and social systems. Obviously, in such conditions, communities are not able to efficiently conduct tourism resource management. Community development strategies are made without considering the environmental consequences of such development of territories; and tourism, as an industry, is currently not included in the list of the industries that have a significant impact on the environment. Therefore, the development of scientific and methodological tools for the sustainable development of united territorial communities and for ensuring a balanced, environmentally friendly tourism resource is relevant today.

The ninth special session of the Governing Council of UNEP in its policy documents noted the problems of sustainable tourism development, especially in developing countries (United Nations, 2003). The main action points in policy document included the following:

a) To increase political support, transparency, and integration;

b) To engage the private sector, encouraging businesses to integrate sustainability in their policies and operations;

c) To improve water and energy efficiency, promote the use of clean energy and reduce waste;

d) To promote sustainable building and construction practices, as well as the incorporation of natural parks in urban areas;

e) To expand knowledge and build capacity;

f) To strengthen the implementation of available tools to stimulate action on the ground and the skills and resources for effective implementation; and

g) To ensure the effective participation of indigenous people and local communities in decisionmaking processes.

The present research is mostly fitting into the context of the action point "c" of the above-said policy document of the UNEP. This topic is especially important for the regions that are in the early stages of tourism development. The purpose of this study is to identify current problems of tourism resource use within the united mountainous territorial communities of Ukraine. The research focuses on mountainous local communities of the Ivano-Frankivsk region having decentralization and resource management in the centre.

\section{Materials and Methods}

A field survey was conducted as the main research method. A survey is the method through which data is collected from the selected group of respondents (Brannen, 2017). The survey can provide information that is not always reflected in written sources or available through natural observation. The goal of this survey was to gather data about the resources (mainly electricity and drainage) consumption, and to estimate waste generation in the study area during the active tourism season. The survey participants were the managers of hospitality establishments. Despite the limitations of this method, it was the only viable method for investigating this case.

Main parameters selected for this inquiry include the volume of water consumption (in the form of drainage), quantity of solid waste disposal, and the magnitude of electricity consumed. The excessive resource consumption by the surveyed hospitality institutions leads to serious environmental problems in mountain communities of the Ivano-Frankivsk region. The field survey was conducted during the "active" tourist season: July-August 2019. The hospitality establishments that use centralized heating systems maintain records of water use, sewerage, waste disposal, and electricity consumption. Geographically, "mountainous areas" in the Ivano-Frankivsk region were covered for this study. The hospitality establishments that had electronic communication were selected for the ease of data collection. Moreover, the hospitality 
establishments were divided into 3 categories based on the size of their services: rural estates, small hotels (up to 50 occupancies), and hotels with 50 or more occupancies having luxury facilities, health services, and pool services.

The survey contained a small number of questions that were asked in order to ensure a high number of responses. These are structured questions (see Appendix 1) about the type of facility, its capacity, the availability of health services, usage of water, and the number of customers during one month of active tourist season (July to August). The questions assessed the water consumption, sewage production, electricity consumption, and solid waste removed in hospitality establishments. The survey questions were sent to all 52 registered hospitality establishments situated in the mountain areas of the region. Out of 52 establishments contacted, 16 establishments (over $30 \%$ of all establishments) responded (6 rural estates, 5 small hotels, and 5 luxury hotels). Initially, an assumption was that hotel managers were interested in this topic in general and were ready to cooperate for environmental sustainability. A small number of hotel managers were also interested in optimizing resource consumption and the contribution of their hotel to the environment. But they did not respond as were expected to do. The low rate of responses from the respondents can be attributed to the fact that there was a fear among the respondents that the information would be disclosed and disseminated. This fear has a reason. In fact, management of resources is often done not fully legally, and fictitious records are reported to regulatory authorities.

\section{Results and Discussion}

In 2017, there were 274 establishments in Ivano-Frankivsk region, but at the time of this survey in the region, only 67 hospitality establishments were reported (Regional Department of Statistics of the IvanoFrankivsk Region, 2020). Probably, such a sharp decrease in the numbers is due to the implementation of strict European directives and recommendations for the collection of statistics in Ukraine since 2018. The new data collection methodology does not consider the small commercial structures that are registered as special legal entities with limited turnover, which is common for most of the hotel businesses in the region. In the hotel industry of the Ivano-Frankivsk region, rural estates occupy an important place. At least 55\% of hospitality establishments usually do not have any legal status in the form of commercial enterprises and are not subject to mandatory official statistical identification. The hospitality establishments are distributed in the districts of the region very unevenly and are located mostly in the traditional mountain tourist destinations. Of them, more than $60 \%$ are located in the territory of Yaremche united community. Such a high density of hospitality establishments at one location causes the problems of unsustainable resource utilization, especially when looked at from small mountain contexts.

Table 1. Tourism resource use in the Ivano-Frankivsk region during the survey period (2019)

\begin{tabular}{|c|c|c|c|c|c|c|}
\hline \multirow{2}{*}{$\begin{array}{l}\text { Average values of } \\
\text { resource and waste } \\
\text { consumption/types of } \\
\text { hospitality } \\
\text { establishments }\end{array}$} & \multicolumn{2}{|c|}{$\begin{array}{c}\text { Volume of solid waste } \\
\text { disposal ( } k g)\end{array}$} & \multicolumn{2}{|c|}{$\begin{array}{l}\text { Electricity consumption } \\
(k W \times h)\end{array}$} & \multicolumn{2}{|c|}{ Water consumption $(l)$} \\
\hline & $\begin{array}{c}\text { For the } \\
\text { entire stay } \\
\text { of the } \\
\text { tourist }\end{array}$ & $\begin{array}{c}\text { Per day } \\
\text { per } \\
\text { tourist }\end{array}$ & $\begin{array}{c}\text { For the entire } \\
\text { stay of the } \\
\text { tourist }\end{array}$ & $\begin{array}{c}\text { Perday } \\
\text { per } \\
\text { tourist }\end{array}$ & $\begin{array}{c}\text { For the } \\
\text { entire stay } \\
\text { of the } \\
\text { tourist }\end{array}$ & $\begin{array}{l}\text { Per day } \\
\text { per } \\
\text { tourist }\end{array}$ \\
\hline Rural estates & 3.28 & 0.82 & 56.48 & 14.12 & 324.00 & 81.00 \\
\hline Small hotels & 15.64 & 3.91 & 60.20 & 15.05 & 472.00 & 118.00 \\
\hline $\begin{array}{l}\text { Hotels with } \\
\text { recreational complexes }\end{array}$ & 16.12 & 4.03 & 67.28 & 16.82 & 1044.00 & 261.00 \\
\hline
\end{tabular}

On average, guests stay for 4 days in the region (National Tourist Organization of Ukraine, 2020). Using such information, average values of solid waste, electricity consumption and water consumption were estimated and are presented in Table 1. 
Tabulated data of water consumption (drainage), consumed electricity, and solid waste disposal in the surveyed hospitality establishments reflects proportional growth of the tourism manifesting accommodated tourists, capacity, and category of the hospitality establishments. Data in Table 1 is also represented in Figure 1 to 3 . This consumption of said resources by tourists in surveyed hospitality establishments is higher than average consumption by the local population in the area. Similar results were also reported by Davies and Cahill (2000). Thus, the quantity of waste generated in small hotels and luxury hotels is 4.8 and 4.9 times higher, respectively, than in rural estates (Figure 1). Most likely, this is because of the minimal set of services at rural estates and practice of more efficient waste management (for example, the food waste is used for feeding the livestock). The difference between the quantity of waste generated in a luxury hotel and a small hotel is insignificant. The quantity of solid waste generated by tourists was compared with the standards of solid waste generation in different types of households. Such standards are defined by the Ministry of Housing and Communal Services of Ukraine (Ministry of Housing and Communal Services, 2010). This quantity ranges from 0.77 to $1.59 \mathrm{~kg}$ (average $1.2 \mathrm{~kg}$ ) per person per day. Thus, the quantity of waste generated by tourists in all surveyed hospitality establishments is higher, and in small hotels and luxury hotels it is 3.2 and 3.4 times higher than the standards for the local residents. For luxury hotels, the permissible amount of solid waste per hotel (not per tourist) is $0.55 \mathrm{~kg}$ per day. From the findings of the solid waste generation in surveyed hotels, the gravity of problem can be understood when a hotel reaches significant levels of occupancy.

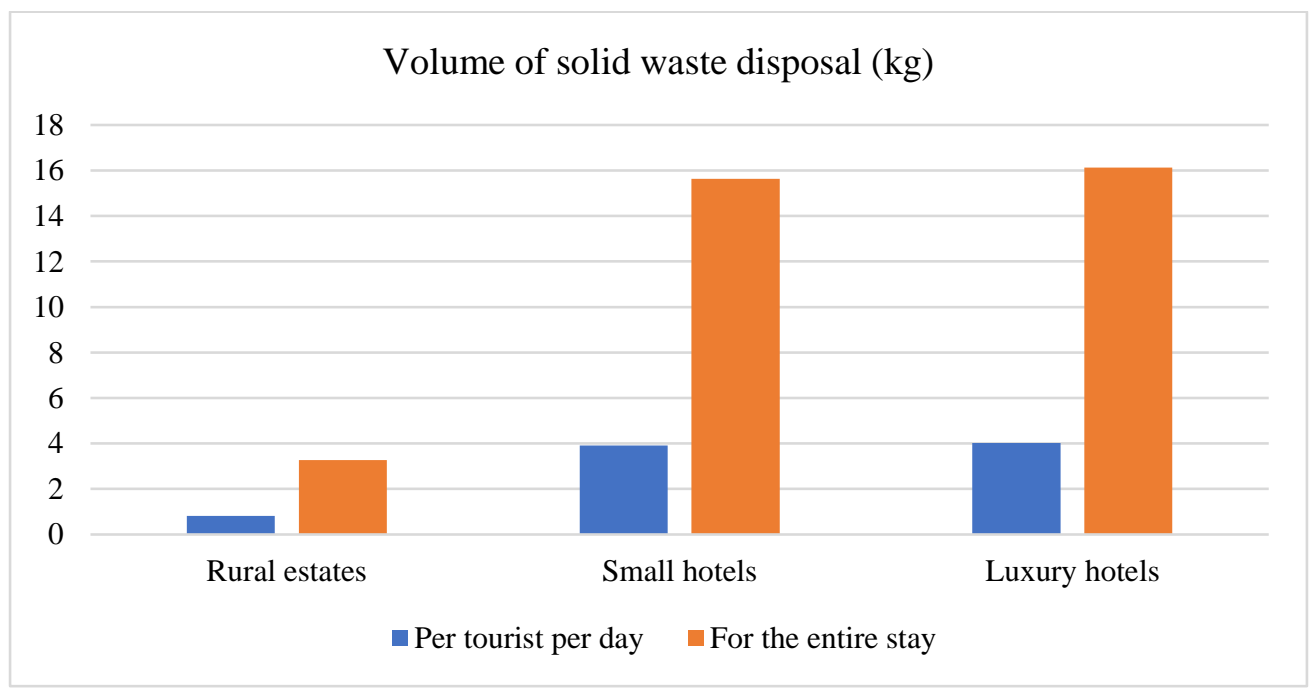

Figure 1: Illustration based on table 1 data of solid waste disposal

The amount of electricity consumed in hospitality facilities per tourist varies from $14.12 \mathrm{kWh}$ in rural estates to $16.82 \mathrm{kWh}$ in luxury hotels. The difference in electricity consumption is insignificant as illustrated in Figure 2. The planning of life support systems of the settlements is guided by the State building standards that outline water, electricity and gas consumption per person per month. In accordance with these standards, for a family of 4 people the rate of electricity consumption per month is $240 \mathrm{kWh}$ or $2 \mathrm{kWh}$ per person per day (Cabinet of Ministers of Ukraine, 2014b). Based on field data, tourists in hospitality establishments consume 7-8 times more electricity than the local residents. These results can be interpreted as the manifestation of the peculiarities of the hotels and the behaviour of tourists. To sustain a level of service, specific measures are taken in the hospitality establishments. Among those are constant lighting of corridors, halls and other public premises, illuminated signs, security, communication systems, etc. Customers usually do not practice energy saving in hotel rooms. Therefore, it is especially important for hospitality establishments to implement energy saving measures. 


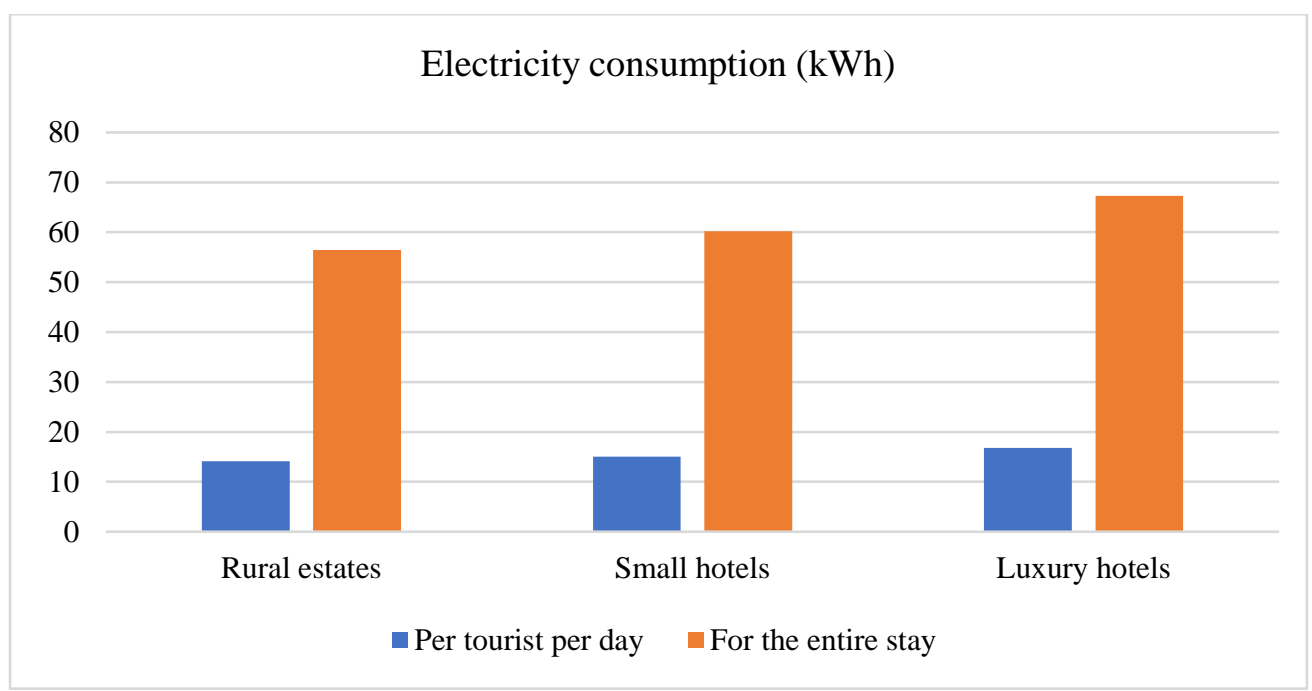

Figure 2: Illustration based on table 1 data of consumed electricity

The results of the survey on water consumption in hospitality establishments indicate that tourists consume 81 litres of water a day in rural estates, 118 litres per day in small hotels and 261 litres per day in luxury hotels (Figure 3). The 2.2-fold higher water use in luxury hotels compared to small hotels is clearly related to the additional services such as pool, and other wellness services with high water consumption. According to established governmental norms, water consumption in Ukrainian households is estimated at around 130 litres per person per day (Cabinet of Ministers of Ukraine, 2014b). The data in Figure 3 indicate that this household consumption limit is 2 times lesser than the actual water consumption in luxury hotels.

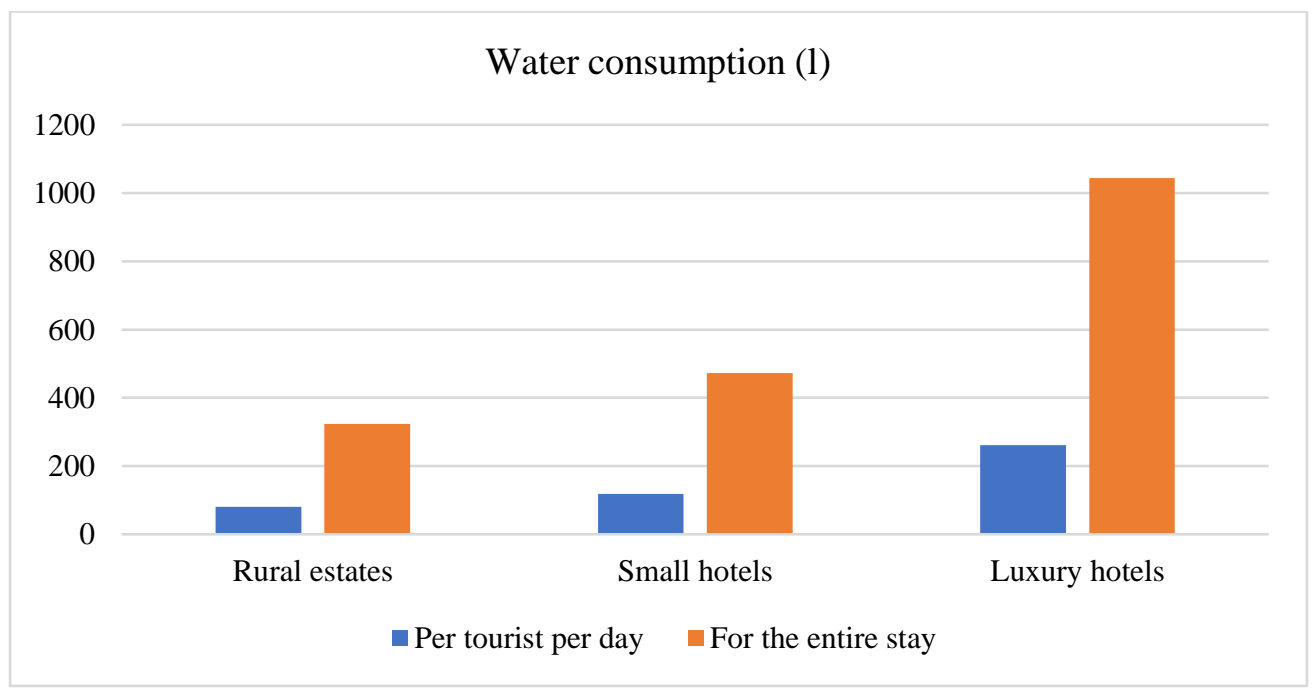

Figure 3: Illustration based on table 1 data of water consumption

The trend of tourism development in the region in recent years shows that the number of tourists grew by 25\% annually from 2015 to 2018 and stabilized at 2.5 million people in 2019 (Department of External Economic Relations and Tourism of Ivano-Frankivsk Region, 2019). However, year 2020 was a failure for tourism in the region due to the COVID-19 pandemic (UNWTO, 2020; National Tourist Organization of Ukraine, 2020b). It is envisaged that after the COVID emergency, a boom of tourism in the mountain will be observed. Mountain destinations have the potential to restore health by virtue of an ecologically clean environment and healthy local food. 
In some of the mountainous communities of the Ivano-Frankivsk region, the number of tourists may often exceed the local population. Statistical data on the number of tourists in some local communities is grossly missing. Such a situation complicates the process of assessing the impact of tourism on the local environment. In such circumstances, the quantification of waste generation, water consumption and wastewater discharge, and the use of electric energy can be useful in assessing the environmental impacts. Findings of this study will help planning the resource use in tourism sector and local community development. As a result, priority can be given to the projects integrating environmentally friendly technologies for waste management, wastewater treatment, and water use. Such activities can be planned while taking into account the growing number of tourists visiting the local communities.

\section{Conclusion}

The development of tourism plays an important role in the socio-economic development of local communities: new jobs are created, a high standard of living is maintained, and bases for the sustainable development of the communities are created. However, such development may be accompanied by the aggravation of environmental problems. This article analysed the main aspects of decentralization, including the function of efficient resource use at the level of local communities. Tourism resource use is invariably accompanied by exacerbation of environmental problems in the community due to excessive consumption of water resources and energy, and waste generation. The solid waste generated by tourists in hospitality establishments within the mountainous united communities were estimated. The water consumption and electricity consumption of a tourist during the stay in a hospitality establishment are also estimated. Recommendation is drawn to include the ecological components in the process of preparing strategic development plans for mountain territories.

The findings and inferences can be used to plan the livelihood systems of mountainous communities that rely on tourism development, and develop strategic plans for tourism resource use within them. In addition, the results can also be used by the managers of hotel establishments or the planners of future hotel complexes while properly preparing the infrastructural plans of accommodations for the tourists. They can reduce the consumption of resources, especially water and electricity, if use the findings of this study.

\section{References}

Bashir, S. and Goswami, S. (2016). Tourism induced challenges in municipal solid waste management in hill towns: Case of Pahalgam. Procedia Environmental Sciences, 35: 77-89. DOI: https://doi.org/10.1016/j.proenv.2016.07.048.

Berdanova, O. and Vakulenko, V. (2012). Strategic planning of local development. Practical guide. SwissUkrainian project "Support to decentralization in Ukraine. [ebook] DESPRO. Kyiv: TOV «SofiiaA». Available online at: https://despro.org.ua/media/articles/04_book_berdanova_vakulenko_ctrateg_chne_planuvann.pdf [Accessed on 16 February 2021].

Borodina, O.A. (2016). Theoretical and practical aspects of economics and intellectual property. [online] Volume 14. pp. 104-111. Available online at: http://nbuv.gov.ua/UJRN/Tpaeiv_2016_14_16 [Accessed on 16 February 2021].

Brannen, J. (2017). Mixing methods: Qualitative and quantitative research. London: Routledge. DOI: https://doi.org/10.4324/9781315248813.

Cabinet of Ministers of Ukraine (2014a). The approval of the concept of formation of local self-government and territorial organization of power in Ukraine. Resolution № 333, 01.04.2014. Kyiv, Ukraine. Available online at: https://zakon.rada.gov.ua/laws/show/333-2014-\%D1\%80\#Text [Accessed on 16 February 2021].

Cabinet of Ministers of Ukraine (2014b). About establishment of the state social standards in the field of housing and communal services. Resolution №409, 6.08.2014. Kyiv, Ukraine. Available online at: https://zakon.rada.gov.ua/laws/show/409-2014-\%D0\%BF\#Text [Accessed 10 March 2021]. 
Davies, T. and Cahill, S. (2000). Environmental Implications of the Tourism Industry. Discussion Paper 0014. Resources for the Future, Washington, DC. Available online at: https://www.csu.edu/cerc/documents/EnvironmentalImplicationsTourismIndustry2000.pdf [Accessed 16 Feb. 2021].

Ezeah, C., Fazakerley, J. and Byrne, T. (2015). Tourism Waste Management in the European Union: Lessons Learned from Four Popular EU Tourist Destinations. American Journal of Climate Change, 4: 431-445. DOI: 10.4236/ajcc.2015.45035.

Giulietti, S., Romagosa, F., Fons-Esteve, J. and Schröder, C. (2018). Tourism and the environment: Towards a reporting mechanism in Europe. ETC/ULS Report 01/2018. Universitat Autònoma de Barcelona (UAB), p.116. Available online at: https://www.researchgate.net/profile/FrancescRomagosa/publication/324330475_Tourism_and_the_environment_Towards_a_reporting_mechani sm_in_Europe/links/5acb2761aca272abdc62ae25/Tourism-and-the-environment-Towards-areporting-mechanism-in-Europe.pdf [Accessed on 3 March 2021].

Holden, A. (2016). Environment and Tourism. London: Routledge. DOI: https://doi.org/10.4324/9781315767659.

Holod, A.P. and Novosad, Z.P. (2012). Ecological safety of tourism in the region: nature and ways of implementation. Naukovyi Visnyk NLTU Ukraiiny, 22: 84-88. Available online at: http://nbuv.gov.ua/UJRN/nvnltu_2012_22.3_15 [Accessed 2 March 2021].

Khajuria, A., Yamamoto, Y. and Morioka, T. (2010). Estimation of municipal solid waste generation and landfill area in Asian developing countries. Journal of Environmental Biology, 31(5): 649-654. Available online

at: https://www.researchgate.net/publication/50350008_Estimation_of_municipal_solid_waste_generat ion_and_landfill_area_in_Asian_developing_countries [Accessed 2 March 2021].

Korobeinykova, Y. and Murava, I. (2013). Environmental problems of the development of tourism infrastructure. Carpathian region [online], №1, pp.107-111. Available online at: http://nbuv.gov.ua/UJRN/kkr_2013_1_15 [Accessed on 2 March 2021].

Kutsenko, V.I. (2010). Environmental safety is a prerequisite for the development of the tourism industry. Economy. Management. Innovations [blog]. Available online at: https://tourlib.net/statti_ukr/kucenko2.htm [Accessed on 2 March 2021].

Mateu-Sbert, J., Ricci-Cabello, I., Villalonga-Olives, E. and Cabeza-Irigoyen, E. (2013). The Impact of Tourism as Municipal Solid Waste Generation: The Case of Menorca Island (Spain). Waste Management, 33: 2589-2593. DOI: https://doi.org/10.1016/j.wasman.2013.08.007.

Mihai, F. (2013). Tourism implications for local waste management. Case study: Neamţ County, Romania. Present Environment and Sustainable Development, 7(1): 214-221. Available online at: https://hal.archives-ouvertes.fr/hal-01150675/document [Accessed 2 March 2021].

Ministry of Housing and Communal Services (2010). About the statement of the Recommended norms of rendering of services on removal of household waste. Ministry of Housing and Communal Services, Government of Ukraine, Kyiv. Available online at: https://www.gioc.kiev.ua/files/File/75_2010.htm [Accessed 12 March 2021].

Murava, I. and Korobeinykova, Y. (2016). The analysis of the waste problem in a tourist destination as an example of the Carpathian region in Ukraine. Journal of Ecological Engineering, 17(2): 43-51. DOI: https://doi.org/10.12911/22998993/62285.

Nair, S.K. and Jayakumar, C. (2008). A Handbook on Waste Management in Rural Tourism Areas. A Zero Waste Approach. United Nations Development Programme, UNDP - India. Available online at: https://www.no-burn.org/wp-content/uploads/Thanal_UNDP_Handbook-Low-Res.pdf [Accessed 16 February 2021].

National Tourist Organization of Ukraine (2020a). Tourist barometer of Ukraine. National Tourist Organization of Ukraine, Kyiv. Available online at: http://www.ntoukraine.org/assets/files/ntoubarometer-2020.pdf [Accessed 16 February 2021].

National Tourist Organization of Ukraine (2020b). The COVID19 pandemic and its consequences in the field of tourism in Ukraine. National Tourist Organization of Ukraine, Kyiv. Available online at: 
http://www.ntoukraine.org/assets/files/EBRD-COVID19-Report-UKR.pdf [Accessed 16 February 2021].

Perederko, V. (2021). Decentralization reform is almost complete [Blog]. Available online at: https://www.facebook.com/vitaliy.perederko/posts/5233373166702628 [Accessed 16 February 2021].

Peterson, C. (2013). Assessment of Solid Waste Management Practices and Its Vulnerability to Climate Risks in Maldives Tourism Sector. Report of the Ministry of Tourism, Arts and Culture, p.19. Available online

at: https://archive.tourism.gov.mv/downloads/tap/2012/Assessment_of_solid_waste_management_prac tices_and_its_vulnerability_to_climate_risks_in_maldives_tourism_sector.pdf [Accessed 2 March 2021].

Prygara, O. (2014). Ecological problems of tourism and ways to solve them. Current Issues of the Humanities, 8(2014): 404-408. Available online at: http://dspu.edu.ua/hsci/wpcontent/uploads/2017/12/008-66.pdf [Accessed 2 March 2021].

Rabbany, M.G., Afrin, S., Rahman, A., Islam, F. and Hoque, F. (2013). Environmental Effects of Tourism. American Journal of Environment, Energy and Power Research, 1(7): 117-130. Available online at: $\quad$ https://pdfs.semanticscholar.org/4e07/6008d5d6a90de424b9ba03b128461b983d41.pdf [Accessed 2 March 2021].

Regional Department of Statistics in Ivano-Frankivsk region (2020). Economic statistics. Economic activity. Tourism. Collective means of accommodation. Regional Department of Statistics in Ivano-Frankivsk region, Ivano-Frankivsk. Available online at: http://www.ifstat.gov.ua/ [Accessed 3 March 2021].

Sharko, V.V. (2014). Environmental safety as an integral part of tourism development. Scientific Bulletin of Kherson State University. Available online at: https://tourlib.net/statti_ukr/sharko.htm [Accessed on 2 March 2021].

Tkachuk, A., Kashevskyi, V. and Mavko P. (2016). Strategic planning in the community (training module). Kyiv: IKTs sLehalnyi Available online at: https://decentralization.gov.ua/uploads/library/file/84/Strategichne-planuvannya.pdf [Accessed on 16 February 2021].

Tourism Department of the Department of External Economic Relations and Tourism of Ivano-Frankivsk Region (2019). Statistics of tourism. Available online at: http://www.if.gov.ua/ [Accessed 16 February 2021].

United Nations (2003) Governing Council of the United Nations Environment Programme. Proceedings of the Governing Council / Global Environmental Ministerial Forum at its twenty-second session. Available online at: https://wedocs.unep.org/handle/20.500.11822/10645 [Accessed 16 February 2021].

UNWTO (World Tourism Organization) (2020). International tourism and covid - 19. Available online at: https://www.unwto.org/international-tourism-and-covid-19 [Accessed 16 February 2021]. 


\section{Appendix 1: Survey questionnaire}

\begin{tabular}{|c|c|c|c|c|}
\hline 1 & $\begin{array}{l}\text { Name of the } \\
\text { establishment }\end{array}$ & & & \\
\hline 2 & Address & & & \\
\hline 3 & Size & Rural Estate & \multicolumn{2}{|c|}{ Hotel } \\
\hline 4 & $\begin{array}{l}\text { Number of tourist } \\
\text { occupancy }\end{array}$ & less than 10 & $11-50$ & more than 50 \\
\hline 5 & $\begin{array}{l}\text { Which special services } \\
\text { are available? }\end{array}$ & \multicolumn{2}{|c|}{ yes } & no \\
\hline $5 \mathrm{a}$ & Wellness baths & & & \\
\hline $5 b$ & Pool & & & \\
\hline $5 \mathrm{c}$ & Tubs with herbs & & & \\
\hline $5 d$ & $\begin{array}{l}\text { Water services not } \\
\text { listed above }\end{array}$ & & & \\
\hline $5 e$ & $\begin{array}{l}\text { Other additional } \\
\text { services }\end{array}$ & & & \\
\hline 6 & $\begin{array}{l}\text { Number of guests } \\
\text { during July-August }\end{array}$ & & & \\
\hline 7 & $\begin{array}{l}\text { Resource consumption } \\
\text { in this period }\end{array}$ & & & \\
\hline $7 a$ & Consumed water (1) & & & \\
\hline $7 b$ & $\begin{array}{l}\text { Consumed electricity } \\
(\mathrm{kWh})\end{array}$ & & & \\
\hline $7 \mathrm{c}$ & $\begin{array}{l}\text { Solid waste disposed } \\
(\mathrm{kg})\end{array}$ & & & \\
\hline
\end{tabular}




\section{Authors' Declarations and Essential Ethical Compliances}

Authors' Contributions (in accordance with ICMJE criteria for authorship)

This article is $100 \%$ contributed by the sole author. She conceived and designed the research or analysis, collected the data, contributed to data analysis \& interpretation, wrote the article, performed critical revision of the article/paper, edited the article, and supervised and administered the field work.

\section{Funding}

No funding was available for the research conducted for and writing of this paper.

Research involving human bodies (Helsinki Declaration)

Has this research used human subjects for experimentation? No

Research involving animals (ARRIVE Checklist)

Has this research involved animal subjects for experimentation? No

Research involving Plants

During the research, the authors followed the principles of the Convention on Biological Diversity and the Convention on the Trade in Endangered Species of Wild Fauna and Flora.

Research on Indigenous Peoples and/or Traditional Knowledge

Has this research involved Indigenous Peoples as participants or respondents? No

(Optional) PRISMA (Preferred Reporting Items for Systematic Reviews and Meta-Analyses)

Have authors complies with PRISMA standards? No

Competing Interests/Conflict of Interest

Author has no competing financial, professional, or personal interests from other parties or in publishing this manuscript.

\section{Rights and Permissions}

Open Access. This article is licensed under a Creative Commons Attribution 4.0 International License, which permits use, sharing, adaptation, distribution and reproduction in any medium or format, as long as you give appropriate credit to the original author(s) and the source, provide a link to the Creative Commons license, and indicate if changes were made. The images or other third-party material in this article are included in the article's Creative Commons license, unless indicated otherwise in a credit line to the material. If material is not included in the article's Creative Commons license and your intended use is not permitted by statutory regulation or exceeds the permitted use, you will need to obtain permission directly from the copyright holder. To view a copy of this license, visit http://creativecommons.org/licenses/by/4.0/. 